Marwah: Jurnal Perempuan, Agama dan Jender

(p-ISSN: 1412-6095 | e-ISSN: 2407-1587)

Vol. 16, No. 1, 2017, Hal. 1 - 12

\title{
HUBUNGAN FAMILY SUPPORTIVE SUPERVISOR BEHAVIORS DI TEMPAT KERJA DENGAN WORK FAMILY ENRICHMENT PADA PEREMPUAN BEKERJA
}

\author{
HIJRIYATI CUCUANI \\ UIN-SUSKA Riau, Indonesia \\ bijriyati.cucuani@uin-suska.ac.id \\ EKA FITRIYANI \\ UIN-SUSKA Riau, Indonesia \\ eka.fitriyani@,uin-suska.ac.id
}

\begin{abstract}
Lately, Research about work-family on working women more focused on the negative impacts. In fact, it is undeniable that work-family conflict also has positive influences, for example the work family enrichment. As a wife or a mother, woman can feel the added value gained from roles as workers and vice versa. Work family enrichment can be influenced by many sources of family and workplace. Family supportive supervisor behavior, is one factor that comes from the workplace. This study aims to find out if there was correlation between family supportive supervisor behaviors in the workplace with work family enrichment on working women. The population in this study were working women in Pekanbaru who have been married and working in the office for at least seven hours in every day. The 121 samples are determined by incidental sampling technique. Product moment correlation test showed that there were significance correlation between family supportive supervisor behaviors in the workplace with work family enrichment on working women in significance level of $0.00(p<0.01)$ and the correlation coefficient of 0.457. Thus, the supervisor can actively helped working women as subordinates to improve the work family enrichment.
\end{abstract}

Key words: work family enrichment, family supportive supervisor behaviors

\section{ABSTRAK}

Penelitian mengenai peran ganda pada perempuan bekerja selama ini lebih terfokus pada dampak. negatif yang ditimbulkannya. Padabal, tidak dapat dipungkiri bahwa peran ganda juga dapat memberikan pengaruh positif, diantaranya adalab work family enrichment. Sebagai seorang istri ataupun ibu, perempuan dapat merasakan adanya nilai tambah yang didapatkan dari peran sebagai pekerja dan begitu pula sebaliknya. Work family enrichment dapat dipengarubi berbagai sumber dari keluarga dan juga tempat kerja. Family supportive supervisor behavior, merupakan salah satu faktor yang bersumber dari tempat kerja. Penelitian ini bertujuan untuk. mengetabui ada tidak. nya bubungan family supportive supervisor behaviors di tempat kerja dengan work family enrichment pada perempuan bekerja. Populasi penelitian adalah perempuan bekerja di Kota Pekanbaru yang telah menikah dan bekerja di kantor selama minimal tujuh jam dalam setiap seharinya. Sampel sebanyak 121 orang ditentukan berdasarkan teknik incidental sampling. Hasil uji korelasi product moment menunjukean terdapat bubungan family supportive supervisor behaviors di tempat kerja dengan work family enrichment pada wanita bekerja dengan taraf signifikansi sebesar $0.00(p<0.01)$ dan koefisien korelasi sebesar 0.457. Dengan demikian, supervisor dapat secara aktif turut membantu perempuan bekerja sebagai bawahannya untuk meningkatkan work family enrichment.

Kata Kunci: work family enrichment, family supportive supervisor behaviors 


\section{A. PENDAHULUAN}

Penelitian ini mencoba mengeksaminasi hubungan antara family supportive supervisor behavior (FSSB) dan work family enrichment (WFE) pada perempuan bekerja di Pekanbaru. WFE dikonseptualisasi oleh Carlson, Kacmar, Wayne dan Grzywacz sebagai sebuah sisi positif yang sangat memungkinkan diterima seseorang dari berkeluarga sekaligus bekerja. WFE menggambarkan bagaimana keluarga mendapatkan benefit dari peran sebagai pekerja dan bagaimana pekerjaan mendapatkan benefit dari peran seseorang di dalam keluarga (Siu, et al., 2010). Dengan demikian, tampak bahwa WFE berada disisi yang bersebrangan dengan work family conflict (WFC) sebagai dampak negatif yang dirasakan perempuan dari peran gandanya, dalam pekerjaan dan juga keluarga.

WFC tidak dapat dihindari oleh perempuan bekerja. Namun, pada kenyataannya perempuan tetap saja mempertahankan pekerjaannya dan juga keluarganya. Hal ini menandakan bahwa ada keuntungan yang diperoleh oleh seorang perempuan yang telah menikah dengan bekerja. Keuntungan tersebut tidak hanya semata-mata berbentuk fisik, namun juga psikologis. Setidaknya, keuntungan yang dirasakan tersebut ada pada lima aspek sebagaimana yang dijelaskan oleh Greenhaus \& Powel (2006), yaitu keterampilan dan perspektif, psychological dan physical, flexibility dan yang terakhir material.

Sebagaimana yang dijelaskan sebelumnya, WFE berbanding terbalik dengan WFC. Pekerjaan dan stress yang dirasakan perempuan dari rumah maupun tempat kerja dapat berdampak positif dan juga negative. Dari sisi negative, hal tersebut akan menghadapkan perempuan pada konflik peran. Namun sebaliknya, WFE akan didapatkan perempuan apabila hal tersebut menjadi sumber peningkatan keterampilan, pengetahuan dan wawasan yang didapat dari satu peran sehingga dapay memudahkan untuk melaksanakan peran lainnya. Sementara berdasarkan hasil penelitian (Cucuani, 2013) terhadap perempuan bekerja di Pekanbaru, meskipun sebagian besar perempuan bekerja memiliki konflik peran ganda yang relatif rendah, namun masih terdapat hampir 10\% subjek yang memiliki WFC yang tinggi. Perempuan bekerja dengan WFC yang tinggi dikhawatirkan memiliki WFE yang rendah.

WFE menjadi sangat penting untuk digali dan ditingkatkan karena berdasarkan berbagai penelitian, WFE berkaitan dengan perilaku dan sikap kerja yang positif. WFE berkaitan dengan kepuasan kerja, motivasi bekerja, self-improvement, control diri, kemandirian dan komitmen organisasi affective (Hamid \& Amin, 2014). WFE tidak hanya berdampak positif terhadap lingkup pekerjaan, tetapi juga berdampak positif 
terhadap keluarga. Lebih lanjut, Rozumah (Hamid \& Amin, 2014) menjelaskan bahwa kesuksesan perkembangan anak dan prestasi akademik anak berhubungan dengan tingkat pendidikan, pengetahuan luas yang dimiliki seorang ibu. Selain itu, berdasarkan hasil penelitian Jaga, Bagraim dan Williams (2013) diketahui bahwa WFE dapat menurunkan depresi dan kelelahan kerja serta dapat meningkatkan subjective well being seseorang. Greenhaus dan Powell (2006) menambahkan bahwa karyawan yang menerima pengakuan dalam pekerjaan untuk menyelesaikan pekerjaan yang menantang akan menunjukkan rasa harga diri yang tinggi sebagai orangtua dan pasangan. Karyawan yang memiliki anak akan mengembangkan peningkatan level kesabaran pada peran sebagai orangtua dan meningkatkan hubungan kerja dengan rekan dan bawahan.

Oleh sebab itu, perlu digali lebih lanjut mengenai faktor-faktor yang berhubungan dengan WFE agar dapat dioptimalkan. Grzywacz and Marks's (Frone, 2003) menjelaskan bahwa predictor pada WFEserupa dengan WFC. Frone (2003) menyatakan bawah berbagai predictor dari WFC secara garis besar dapat dikelompokkan menjadi dua, yaitu role environment dan personality. Role environment merupakan predictor yang lebih memungkinkan untuk dioptimalkan. Role environment dapat berupa keterlibatan kerja, kepuasan kerja dan keluarga, serta dukungan sosial dari keluarga dan pekerjaan.

House mendefinisikan dukungan sosial sebagai transaksi interpersonal yang termasuk ekspresi adanya perhatian emosional, bantuan peralatan, atau pemberian informasi (Hammer, Kossek, Yragui, Bodner, \& Hanson, 2009). Dukungan sosial dari lingkungan kerja dapat berasal dari rekan kerja, bawahan dan atasan (supervisor). Atasan merupakan orang penting dalam menciptakan suasana nyaman dalam bekerja untuk bawahannya. Dukungan yang yang diberikan atasan untuk mengatasi kesulitan dan masalah yang timbul dari interaksi pekerjaan dan keluarga disebut dengan Family supportive supervisor behavior (FSSB). Hammer, Kossek, Yragui, Bodner \& Hanson (2009) mendefinisikan FSSB sebagai sebuah konstruk di mana atasan memberikan dukungan yang terdiri dari dukungan emosional dan instrumental tentang tuntutan keluarga, sebagai tambahan, ia juga menjadi contoh berperilaku dan kreatif dalam memanajemen tuntutan pekerjaan dan keluarga.

Atasan yang memberikan dukungan emosional dan instrumental serta menjadi role model dalam berperilaku terhadap bawahannya dapat dilihat sebagai seseorang yang tengah memotivasi dan mengajarkan untuk dapat meningkatkan afek positif saat bekerja dan hal tersebut kemudian dapat diaplikasikan pekerja dalam berinteraksi dengan 
anggota keluarganya. Begitupula dengan usaha atasan dalam memanagemen strategi bekerja dan membantu bawahan untuk bersama-sama menyelesaikan permasalahan yang timbul sebagai interaksi peran dalam pekerjaan dan keluarga membantu bawahan dalam belajar mengatasi masalah dengan tanpa merasa tersudut.

Hanya saja, tuntutan pekerjaan serta tanggungjawab tugas atasan yang berat membuat banyak atasan lebih fokus pada penyelesaian tugas dan kurang menaruh perhatian pada kondisi dan kesulitan yang dihadapi bawahannya. Hal tersebut seringkali membuat bawahan kurang termotivasi dalam bekerja sehingga kurang memaknai aktivitas serta manfaat yang didapatkannya dalam bekerja.

Penelitian ini mencoba untuk mencari tahu hubungan Family supportive supervisor behavior dengan work family enrichment pada perempuan bekerja. Hasil dari penelitian ini diharapkan dapat menjadi masukan dan pertimbangan dalam mengidentifikasi masalah dan mengoptimalkan kinerja perempuan bekerja serta membuat kebijakan dan menyusun program yang sesuai dan efektif oleh pimpinan di tempat kerja.

\section{B. TINJAUAN PUSTAKA}

\section{Work Family Enrichment}

Menurut Carlson, Kacmar, Wayne dan Grzywacz (Siu, et al., 2010), para peneliti telah menggunakan beberapa istilah diantaranya positive spillover, facilitation, enhancement and enrichment secara bergantian untuk menjelaskan sisi positif dari interaksi kerja-keluarga. Meski sangat dekat namun masing-masing istilah tersebut berbeda. Enhancement mengacu pada keuntungan dalam sumber (keterampilan, perspektif, dll) dan pengalaman yang menguntungkan karyawan dalam beberapa peran kehidupan. Positive spillover mengacu pada transfer pengalaman positif dari satu peran kehidupan yang lain. Greenhaus dan Powell (2006) Enrichment mengacu pada proses di mana peningkatan kualitas pengalaman dalam peran timbul karena pengalaman positif di peran yang lain. Enrichment dibangun di atas positive spillover dan enhancement, dan literatur menunjukkan bahwa konstruk enrichment jauh lebih kompleks. Menurut Carlson et al. serta Hanson, Hammer dan Colton (Klerk, Hill, Nell, \& koekemoer, 2013), konstruksi seperti work family positive spillover, work family enhancement dan work family facilitation semua dapat dikategorikan di bawah konsep work family enrichment. Kedua konsep work-family enrichment dan family-work enrichment menggabungkan gagasan bahwa pengalaman atau sumber daya dalam satu domain 
(pekerjaan atau keluarga) dapat ditransfer (dituangkan) ke domain lain (keluarga atau pekerjaan). Agar enrichment terjadi, sangat penting bagi karyawan untuk mentransfer keuntungan yang bersumber dari satu peran ke yang lain dan untuk meningkatkan kinerja pada peran yang lain.

Carlson, Kacmar, Wayne dan Grzywacz (Siu, et al., 2010) menjelaskan bahwa work family enrichment adalah sebuah sisi positif yang sangat memungkinkan diterima seseorang dari berkeluarga sekaligus bekerja. Marks (Hamid \& Amin, 2014) menjelaskan bahwa seseorang akan mendapatkan keuntungan dari komitmennya dalam peran gandanya dan apa yang dibutuhkan dalam menyelesaikan tugas disuatu peran dapat berguna dalam penyelesaian tugas peran lainnya. Work family enrichment didefinisikan sebagai sejauh mana pengalaman dalam salah satu peran meningkatkan kualitas hidup, yaitu kinerja atau perasaan dalam peran lain. Work family enrichment juga dapat dipahami sebagai sebuah interaksi antara pekerjaan dan keluarga, dimana pengalaman dan partisipasi di dalam sebuah peran membantu meningkatkan kinerja diperan lainnya (Greenhaus \& Powel, 2006).

Sebagaimana dipaparkan sebelumnya, work family enrichment dapat dijelaskan dari bagaimana sumber (resource) dalam pekerjaan dapat mempengaruhi peningkatan kualitas peran dalam keluarga dan sebaliknya. Sumber adalah aset yang dapat ditarik pada saat dibutuhkan untuk memecahkan masalah atau mengatasi situasi yang menantang. Sumber tersebut menurut Greenhaus \& Powel (2006) terdiri dari : (1) keterampilan dan perspektif, mengacu pada kognisi, interpersonal and keterampilan multi-tasking serta cara dalam mendefinisikan masalah dan situasi., (2) psychological dan physical, mengarah pada harga diri, optimisme, kesehatan fisik, (3) social-capital, mengacu pada keterpengaruhan and informasi yang diperoleh dari relasi dalam peran dipekerjaan dan keluarga, (4) flexibility, mengarah pada kebijaksanaan dalam mengalokasikan waktu, jarak dan lokasi yang dibutuhkan untuk memenuhi kebutuhan suatu peran, dan (5) material, mengarah pada uang dan pengharaan yang diperoleh dari domain kerja dan keluarga.

Secara umum, Greenhaus \& Powell menjelaskan bahwa sumber-sumber tersebut dapat memberikan efek melalui dua jalur yaitu instrumental dan afektif terhadap antar peran. Kelima sumber di atas dikatakan dapat menjadi Instrumental path karena memiliki efek berperan langsung pada kinerja dalam peran lain. Selain itu, sumber yang dihasilkan dalam peran satu juga dapat dapat memberikan affective path 
yang mempengaruhi (emosi positif dan sikap) peran lainnya (Klerk, Hill, Nell, \& koekemoer, 2013). Beberapa ahli menjelaskan bahwa pekerja yang mempercayai bahwa kehidupan keluarganya akan memberikan mereka cara baru dalam berinteraksi dengan rekan kerja atau dapat meningkatkan kemampuan mereka untuk dapat multi tasking dalam bekerja, atau dapat pula sebaliknya. Contohnya saja, pekerja yang mempelajari keterampilan pemecahan masalah pada pelatihan kerja, dapat diterapkannya dalam menyelesaikan masalah dalam keluarga sehingga dapat menyelesaikan masalah dengan anak ataupun pasangan dengan lebih efektif. Affective pathway dapat dijelaskan dari seseorang yang meninggalkan pekerjaan dengan suasana hati yang positif akan lebih merespon anggota keluarga dengan lebih positif, sabar, ceria sehingga dapat lebih meningkatkan performanya sebagai orang tua ataupun pasangan (Carlson, Kacmar, \& Ho, 2006).

Carlson, Kacmar \& Ho (2006) menjabarkan tiga dimensi dari work family enrichment untuk masing-masing arah (pekerjaan dan rumah). Dimensi untuk pekerjaan yang mempengaruhi enrichment pada pekerjaan (family work enrichment) adalah development, affect, and capital were prevalent. Dalam arah pekerjaan yang mempengaruhi enrichment pada keluarga (work family enrichment) dimensinya adalah development, affect, and efficiency.

\section{Family Supportive Supervisor Behavior}

Dukungan sosial dari atasan adalah sebuah hal penting untuk dipelajari karena dapat mengurangi efek negatif stressor dari pekerjaan dan keluarga (Hammer, Kossek, Yragui, Bodner \& Hanson, 2009). Mengingat peran kunci dari supervisor dalam menafsirkan dan memberlakukan kebijakan organisasi formal dan praktek informal di tempat kerja.

Hammer, Kossek, Zimmerman, \& Daniels menjelaskan bahwa para peneliti sudah mulai menguji berbagai perilaku pemimpin (supervisor) yang dapat mendorong terbentuknya iklim yang mendukung keluarga yang kemudian disebut dengan istilah family supportive supervisor behaviors (Johnson, 2014). Family-supportive supervisors behavior adalah perilaku atasan yang menunjukkan empati dengan keinginan karyawan untuk mencari keseimbangan antara tanggung jawab pekerjaan dan keluarga (Thomas \& Ganster, 1995). Hammer, Kossek, Yragui, Bodner \& Hanson (2009) mendefinisikan FSSB sebagai sebuah konstruk di mana atasan memberikan dukungan yang terdiri dari dukungan emosional dan instrumental tentang tuntutan keluarga, sebagai 
tambahan, ia juga menjadi contoh berperilaku dan kreatif dalam memanajemen tuntutan pekerjaan dan keluarga.

FSSB merupakan dukungan atasan yang terdiri dari dukungan emosional (emotional support) dan instrumental (instrumental support) tentang tuntutan keluarga, sebagai tambahan, ia juga menjadi contoh berperilaku dan kreatif dalam memanajemen tuntutan pekerjaan dan keluarga (Hammer, Kossek, Yragui, Bodner \& Hanson, 2009). Dimensi dukungan emosional berpusat seputar persepsi yang dirasakan seseorang bahwa ia dianggap dan dihargai oleh atasannya. Dukungan emosional yang diberikan atasan mencakup sejauh mana atasan membuat karyawannya merasa nyaman mendisukusikan hal-hal yang berkaitan dengan keluarga, mengekspresikan keprihatinan terhadap tanggungjawab pekerjaan yang berdampak pada keluarga, dan menunjukkan respek, pengertian, simpati dan sensitivitas terhadap tanggunggung jawab keluarga. Misalnya, seorang atasan yang menanyakan hal sederhana mengenai apa yang dirasakan karyawannya setelah mengalami perceraian yang sulit. Dukungan instrumental mengarah pada seorang atasan yang bereaksi dan menanyakan tentang pekerjaan dan kebutuhan keluarganya di pekerjaan. Ini adalah sejauh mana pengawas menyediakan sumber daya sehari-hari atau jasa untuk membantu karyawan dalam upaya mereka untuk berhasil mengelola tanggung jawab ganda mereka dalam peran pekerjaan dan keluarga. Dimensi ini dapat termasuk bereaksi terhadap permintaan penjadwalan yang lebih fleksibilitas, perlu menafsirkan kebijakan dan praktek, dan mengelola jadwal kerja rutin untuk memastikan bahwa tugas-tugas karyawan dapat dilakukan.

Ketika atasan mencontohkan perilaku memasukkan anakknya ke tempat penitipan yang disediakan oleh perusahaan atau instansi, itu berarti ia sedang mendemontrasikan role modeling behavior. Berbagi ide dan saran tentang strategi yang biasanya berhasil digunakan dalam mengatur tuntutan peran dalam pekerjaan dan keluarga akan sangat membantu karyawan. Dan yang terakhir, creative work-family management mencakup tindakan inisiatif merestruktur pekerjaan untuk menolong karyawan meningkatkan efektivitas di dalam dan diluar pekerjaan. Dalam hal ini, dibutuhkan manjemen yang lebih tinggi tentang sebuah kebijakan yang ramah keluarga (Johnson, 2014). Perilaku ini dapat mencakup perubahan besar dalam waktu, tempat dan cara menyelesaikan pekerjaan yang secara simultan menyeimbangkan tanggungjawab dan kebutuhan dari keluarga, perusahaan, konsumen dan rekan kerja. 
Dengan demikian, creative work-family management bersifat proaktif, lebih strategic dan inovatif.

\section{METODE PENELITIAN}

Subjek dalam penelitian ini adalah perempuan bekerja yang tinggal dan bekerja di Kota Pekanbaru. Sampel diambil dengan teknik incidental sampling di beberapa instansi baik negeri maupun swasta. Jumlah sampel yang digunakan adalah 121 orang, yang terdiri dari pekerja di dinas pemerintahan, instansi pendidikan dan perbankan. Subjek penelitian sebagian besar bersuku Melayu 43,8\%, sementara sisanya bersuku Minang $28,1 \%$, Jawa $9,9 \%$, Batak 5,8\%, dan suku lainnya sebanyak 12,4\%. Tingkat pendidikan subjek bervariasi dengan sebaran sebagai berikut; Sarjana 52,\%, SMA 17,4\%, Pascasarjana sebanyak 14,9\%, dan Akademi sebanyak 8 orang 6,6\%, dan di bawah pendidikan SMA 8,3\%. Gambaran pendapatan subjek per bulan adalah; 1,5-3 juta 38,8\%, 4-6 juta 37,2\%, kurang dari 1,5 juta 8,3\%, pendapatan 7-10 juta 5,8\%, pendapatan di atas 10 juta 2,5\%, dan tidak teridentifikasi sebanyak 7,4\%. Adapun data dari jumlah anak subjek adalah dua orang 28,9\%, jumlah anak 1 dan 3 memiliki persentase yang sama yaitu $24,8 \%$, 4 orang anak $7,4 \%$, dan lebih dari $40,8 \%$, sementara $13,2 \%$ tidak teridentifikasi.

Teknik pengambilan data adalah dengan menggunakan skala psikologis yang terdiri dari Skala Work Family Enrichment dan Skala Family Supportive Supervisor Bebaviors. Skala Work Family Enrichment yang digunakan merupakan skala yang dibuat oleh Carlson, dkk tahun 2006, skala terdiri dari 18 aitem pernyataan disusun berdasarkan model skala Likert dengan menggunakan lima alternatif jawaban yaitu Sangat Sesuai (SS), Sesuai (S), Netral (N), Tidak Sesuai (TS), Sangat Tidak Sesuai (STS) yang terdiri dari pernyataan favorabel dan unfavorabel. Skala Family Supportive Supervisor Behaviors (FSSB) yang digunakan adalah Skala yang dibuat oleh Hammer, dkk tahun 2009. Skala terdiri dari 14 aitem pernyataan disusun berdasarkan model skala Likert dengan menggunakan lima alternatif jawaban yaitu Sangat Sesuai (SS), Sesuai (S), Netral (N), Tidak Sesuai (TS), Sangat Tidak Sesuai (STS) yang terdiri dari pernyataan favorabel dan unfavorabel.

Data penelitian untuk menguji hipotesis diolah dengan metode kuantitatifkorelasi yaitu dengan menggunakan Product Moment untuk melihat Hubungan Family Supportive Supervisor Behaviors di Tempat Kerja dengan Work Family Enrichment pada Perempuan Bekerja. 


\section{HASIL DAN PEMBAHASAN}

\section{Uji Normalitas dan Linearitas}

Berdasarkan hasil uji normalitas diketahui bahwa Rasio Skewness dan Kurtosis kedua variabel berada pada rentang -2 sampai +2 , maka dapat disimpulkan sebaran data normal. Sementara itu, uji linieritas pada variabel Family Supportive Supervisor Behaviors dan Work Family Enrichment pada perempuan bekerja diketahui $\mathrm{F}=31,474$ dengan signifikansi $0.000(\mathrm{p} \leq 0.05)$.

\section{Deskripsi Data}

Deskripsi data di atas menunjukkan bahwa Work Family Enrichment subjek berada pada kategori tinggi sebanyak 73 orang (60,33\%), subjek pada kategori sangat tinggi sebanyak 40 orang $(33,06 \%)$ dan selanjutnya pada subjek pada kategori sedang sebanyak 7 orang (5,79\%). Sedangkan data Family Supportive Supervisor Behaviors subjek pada kategori tinggi sebanyak 52 orang (42,98\%), kategori sedang sebanyak 36 orang $(29,79 \%)$ dan selanjutnya pada kategori sangat tinggi sebanyak 22 orang $(18,18 \%)$ dan kategori rendah 7 orang $(5,79 \%)$.

\section{Uji Hipotesis}

Tabel 1. Hasil Uji Hipotesis

\begin{tabular}{llll}
\hline & & WFE & \multicolumn{1}{c}{ FSS } \\
\hline \multirow{2}{*}{ WFE } & Pearson Correlation & 1 &, $457^{* *}$ \\
& Sig. (2-tailed) &, 000 \\
\hline \multirow{2}{*}{ FSS } & $\mathrm{N}$ & 121 & 121 \\
\cline { 2 - 4 } & Pearson Correlation &, $457^{* *}$ & 1 \\
\cline { 2 - 4 } & Sig. (2-tailed) &, 000 & \\
\hline \multicolumn{4}{c}{ **. Correlation is significant at the 0.01 level (2-tailed). }
\end{tabular}

Tabel 2. Hasil Uji Hipotesis

\begin{tabular}{lcccc}
\hline \multirow{2}{*}{ Kategori } & \multicolumn{2}{c}{ WFE } & \multicolumn{2}{c}{ FSSB } \\
\cline { 2 - 5 } & $\mathbf{F}$ & $\mathbf{0}$ & $\mathbf{F}$ & $\mathbf{\%}$ \\
\hline Sangat Tinggi & 40 & 33.06 & 22 & 18.18 \\
\hline Tinggi & 73 & 60.33 & 52 & 42.98 \\
\hline Sedang & 7 & 5.79 & 36 & 29.75 \\
\hline Rendah & 1 & 0.83 & 7 & 5.79 \\
\hline Sangat Rendah & 0 & 0 & 4 & 3.31 \\
\hline
\end{tabular}

Berdasarkan hasil analisis product moment diperoleh hasil koefisien korelasi (r) sebesar 0.457 dengan probabilitas $0.000(\mathrm{p}<0.01)$, maka hipotesis yang diajukan dalam penelitian ini "terdapat hubungan antara Family Supportive Supervisor Behaviors di 
tempat kerja dengan Work Family Enrichment pada perempuan bekerja" diterima. Artinya Semakin tinggi Family Supportive Supervisor Behaviors di tempat kerja, maka semakin tinggi Work Family Enrichment pada perempuan bekerja.

\section{Pembahasan}

Berdasarkan olah data penelitian, didapatkan bahwa terdapat hubungan yang signifikan Family-supportive supervisors behavior di tempat kerja dengan work family enrichment pada perempuan bekerja. Hal ini ditunjukkan dari taraf signifikansi yang diperoleh sebesar $0.00(\mathrm{p}<0.01)$ dan koefisien korelasi sebesar 0.457. Dengan demikian, dapat dijelaskan bahwa jika Family-supportive supervisors behavior tinggi maka work family enrichment pada perempuan bekerja juga akan tinggi.

Dalam penelitian Abendroth \& den Dulk (2011), Behson (2005) Thompson, Beauvais \& Lyness (1999) menunjukkan hasil bahwa supervisory support adalah vital ketika bagi karyawan hal tersebut hadir sebagai penyeimbang antara tanggung jawab pekerjaan dan keluarga (Neglia, 2015). Atasan yang memberikan dukungan emosi yang tinggi kepada karyawan akan membuat karyawan merasa nyaman, berharga dan tidak sendiri. Pemenuhan kebutuhan emosi dapat membantu karyawan lebih optimal dan focus dalam menyelesaikan tugas. Selain itu, dukungan emosi yang didapat dari atasan dan efek positif yang ditimbulkan mengajarkan pada karyawan pentingnya memenuhi kebutuhan emosi keluarga. Perasaan nyaman, dan berharga juga membuat karyawan kembali ke rumah menghadapi keluarga dan tugas di rumah dengan emosi yang positif.

Dukungan instrumental dari atasan membantu bawahan salah satunya dalam mengatasi time based conflict dalam konflik peran ganda. Meskipun pemenuhan kebutuhan waktu untuk keluarga sulit secara penuh untuk diwujudkan oleh perempuan bekerja, namun dukungan instrumental mampu mengurangi ketegangan waktu tersebut. Adanya peluang untuk pengaturan waktu kerja secara mandiri pada perempuan bekerja meningkatkan kemandirian dan kemampuan pengaturan waktu dalam keluarga, begitu pula sebaliknya.

Role modeling behavior yang ditunjukkan oleh atasan kepada perempuan bekerja dalam mencegah atau menghadapi masalah yang terkait dengan pekerjaan dan keluarga dapat menambah wawasan, pengetahuan dan keterampilan. Keterampilan yang dimaksud termasuk juga keterampilan menyelesaikan masalah secara efektif, 
sehingga pekerja perempuan terbiasa dan mampu menyelesaikan masalah baik di tempat kerja maupun di rumah.

Creative work-family management tidak hanya berusaha menyelesaikan permasalahan pekerja, namun lebih kepada strategi dalam memberikan keuntungan dangan meminimalkan kerugian di kedua belah pihak, pekerja dan perusahaan. Dengan demikian, pekerja perempuan tidak hanya menuntut untuk dipahami namun juga berusaha untuk memberikan yang terbaik kepada perusahaan. Adanya creative work-family management yang ditunjukkan atasan akan menimbulkan rasa aman karena diperhatikan dan menjadi bagian dari perusahaan. Membuat pekerja merasa nyaman, dapat belajar dalam menghadapi mengatasi masalah terkait tuntutan peran di pekerjaan dan keluarga. membantu pekerja perempuan memenuhi kebutuhan keluarga mereka dan membebaskan mereka dari kekhawatiran mengenai keluarga.

Penelitian sebelumnya telah menunjukkan bahwa karyawan dapat lebih baik dalam mengatasi konflik peran keluarga-pekerjaan dan mengalami tingkat yang lebih rendah dari konflik kerja-keluarga ketika karyawan merasakan bahwa atasan mereka memberikan dukungan (Breaugh \& Frye, 2008; Frye \& Breaugh, 2004; Lapierre \& Allen, 2006 ; Rahasia \& Sprang, 2001). Dukungan sosial dari atasan adalah sebuah hal penting untuk dipelajari karena dapat mengurangi efek negatif dari stressor dari pekerjaan dan keluarga), mengingat peran kunci dari supervisor dalam menafsirkan dan memberlakukan kebijakan organisasi formal dan praktek informal di tempat kerja Hammer, Kossek, Yragui, Bodner \& Hanson (2009). Selain itu, karyawan yang merasa bahwa dukungan dari lingkungan kerja akan lebih mungkin untuk menampilkan kinerja yang lebih baik (Booth \& Matthews, 2012).

\section{E. Simpulan}

Berdasarkan penelitian yang telah dilakukan maka dapat disimpulkan bahwa terdapat hubungan antara Family Supportive Supervisor Behaviors di tempat kerja dengan Work Family Enrichment pada perempuan bekerja. Artinya Semakin tinggi Family Supportive Supervisor Behaviors di tempat kerja, maka semakin tinggi Work Family Enrichment pada perempuan bekerja. 


\section{DAFTAR REFERENSI}

Carlson, D. S., Kacmar, K. M., \& Ho, J, Measuring the positive side of the work-family interface: Development and validation of a work-family enrichment scale. Journal of Vocational Behavior , 131-164, 2006.

Cucuani, H. Konflik Peran Ganda: Memahami Coping Strategi pada Wanita Bekerja. Pekanbaru: UIN Suska Riau, 2013.

Frone, M. R. Work-family Balance. In J. Quick, \& L. Tetrick, Handbook of occupational health psychology (pp. 143-162). Washington D.C: American Psychology Association, 2003.

Greenhaus, J., \& Powel, G. When Work and family are allies: A theory of work family Enrichment. Academy of Management Review, 72-92, 2006.

Hamid, R. A., \& Amin, S. M. Work-Family Conflict and Work-Family Enrichment and Their Consequences in Malaysia. Middle-East Journal of Scientific Research , 729-73, 2014.

Hammer, L. B., Kossek, E. E., Yragui, N. L., Bodner, T. E., \& Hanson, G. C. Development and validation of a multidimentional measure of familily supportive supervision behaviors (FSSB). J Manage , 837-856, 2009.

Johnson, D. A. The Effects of Family Supportive Supervisor Behaviors (FSSB) on Work and Health Related Outcomes. Kentucky: Eastern Kentucky University, 2014.

Klerk, M. D., Hill, C., Nell, A. J., \& koekemoer, E. The development of the MACE workfamily enrichment instrument. SA Journal of Industrial Psychology , 1-16, 2013.

Neglia, J. The Role of Demographics: Who Engages in and Who Benefits from Family Supportive Supervisor Behavior. Kennesaw: Kennesaw State University, 2015.

Siu, O.-L., Lu, J.-f., Brough, P., Lu, C.-q., Baker, A. B., Kalliath, T., et al. Role Resources and Work-Family Enrichment: The Role of Work Engagement. vocational Behavior, 2010.

Thomas, L. T., \& Ganster, D. C. Impact of Family-Supportive Work Variables on WorkFamily Conflict and Strain: A Control Perspective. Journal of Applied Psychology, 615, 1995. 